\title{
Mangrove Ecosystem Biodiversity in Malacca Strait and Its Economic Values to Local Community: A Case Study in Riau Coastline
}

\author{
Zulkarnaini*, Yuliasamaya, Syafriadiman \\ Study Program of Environmental Sciences, Universitas Riau, Jalan Pattimura No. 9, Pekanbaru 28131, Indonesia
}

Corresponding Author Email: zul.karnaini@lecturer.unri.ac.id

https://doi.org/10.18280/ijsdp.160813

Received: 19 October 2021

Accepted: 17 December 2021

\section{Keywords:}

mangrove ecosystem, economic values,

Riau coastline

\begin{abstract}
The mangrove ecosystem holds a lot of potentials to be utilized by local communities in the Riau Coastline. Therefore, this study was carried out to assess the biodiversity of flora and fauna in the Riau Coastline mangrove ecosystem and its impacts on local communities. The transect was performed to identify soil conditions, distribution, and the dominance of flora species, while field observations and interviews with residents were conducted to determine the presence of fauna and discover the ecosystem's benefit to the local community's economy. Based on the results, Rhizophora mucronata and Rhizophora apiculata has the highest relative dominance (RDC) and important value index in all observed stations. On the other hand, the fish/water biota species has the highest diversity and have economic that mostly serve as a catch for local fishermen. Ecotourism is also encouraged to boost the community's economy and aid ecological learning for sustainability purposes. The mangrove ecosystem's existence remains sustainable because fisheries are the main commodity, however, logging is less desirable as a source of income.
\end{abstract}

\section{INTRODUCTION}

The mangrove ecosystem is a unique ecosystem with characteristic fauna and flora morphology [1] and grows in river mouths, tidal areas, or seasides [1-3] as a transition of terrestrial species [4]. Furthermore, the morphology of mangrove plants is a combination of the characteristics of aquatic and terrestrial plants and has a root system generally in the form of pneumatophores or breath roots [1] as well as stilt roots [3]. This type of rooting is a technique used by plants to adapt to poorly oxygenated or even anaerobic substrate conditions [5]. According to Sukuryadi et al. [6] and Mahmood et al. [7], the mangrove ecosystem does support not only the growth of flora but also fauna, therefore, suitable habitat for various kinds of biota due to the wide coverage area $[6,8]$. Meanwhile, the fauna present in this ecosystem includes endemic, protected, and commodity animals, especially fish, serving as a source of livelihood for the surrounding community $[8,9]$.

Indonesia has a large mangrove ecosystem, comprising almost $23 \%$ of the world's total mangrove area, at $3,489,140.68 \mathrm{Ha}[10]$. However, only $1,671,140.75 \mathrm{Ha}$ of this area is in good condition, while $1,817,999.93$. The Riau Coastline, situated in Malacca Strait, is an area with unique edaphic environmental conditions due to the presence of mangrove vegetation growing on peatlands [1], and with consequently high biodiversity. Previous studies by Ono et al., [11], and Sukendi and Mariana [1], described biodiversity as natural wealth with economic, social, and ecological value.

In the last two decades, the mangrove ecosystem's existence has drastically decreased in quality and is now generally found around river estuaries with a thickness of 10-100 meters. This is caused by mangrove deforestation and human activities such as land-use development, agriculture expansion, overexploitation, and natural disaster such as tsunami [4]. This condition certainly needs to be evaluated to ensure improvements in the future.

Mangroves are defined as vegetation growing in coastal estuarine environments, in this case, areas with socioeconomic and environmental significance [9, 12-14]. Thus, the socio-economic benefits of mangroves for local communities, particularly coastal communities, must be known while assessing the ecosystem's management [12]. Coastal communities are directly exposed to harsh ecosystem conditions and depend on the use of coastal and marine resources as sources of livelihoods and are, therefore, unique. Fishermen are the dominant coastal community and are categorized as poorer compared to the families of farmers or craftsmen. Therefore, social and economic aspects must be discussed in the assessment of coastal area management to obtain further information.

Mangrove's ecosystem resources provide various benefits at both the local, national, and global levels [2, 6, 8]. The mangrove forest ecosystem offers a range of ecosystem services such as supporting, provisioning, cultural, and regulating services to the livelihood of millions of people [4]. These consist of tangible benefits in the form of mangrove ecosystem products, non-timber ecosystem products including fruit, and latex, as well as intangible benefits, including environmental protection, and genetic diversity [13]. Also, the mangroves ecosystem adapts to the growth of flora and fauna in addition to compensating for the influence of seawater intrusion on the soil $[3,5]$. This ecosystem is a habitat for various fish species, and is, therefore, a source of livelihood for local fishermen [15-17].

The transect method is a common method used in assessing 
the existence of mangrove vegetation [4]. Also, the characteristics of tropical mangrove soil correlate with the forest structural attributes [5]. The existence of the mangrove ecosystem is also influenced by the local community participation and awareness in preserving mangrove ecosystem sustainability [6]. The collaboration in physical observation and local social condition assessment in mangrove forest utilization could summarize the sustainability of the mangrove ecosystem [7].

Riau coastline has a large mangrove ecosystem located in Malacca Strait which supports the livelihood of local communities. The present mangrove ecosystem has economic values such as the source of fisheries, woods, and ecotourism. Several researches have been conducted on mangrove biodiversity in the Indonesian coastline $[1,2,6,8]$. On the other hand, the study of the impact of mangrove ecosystem biodiversity on the local community especially on the Sumatra Coastline is still lacking.

Since it has had a great impact on the local community economy, the presence of the mangrove ecosystem in Riau coastline, it is important to assess mangrove biodiversity so that it can be utilized sustainably. This study, therefore, aims to collect data on the condition of the Riau Coastline area's mangrove ecosystem. An assessment was carried out on the soil, flora, and fauna conditions and the impact on the lives of the surrounding community, comprising mostly fishermen. This study's results are expected to be a benchmark for mangrove conservation in supporting the economic life of coastal communities, both at the local and regional levels.

\section{MATERIALS AND METHODS}

\subsection{Sampling area}

Figure 1 shows the four observation stations within the Riau Coastline area used in this study. Each observation station was located close to a fishing village dependent on the mangrove ecosystem as a source of livelihood. The four observation stations are related to economic, socio-cultural, and ecological activities. Also, the observation stations have the highest access for the community activities, such as ecotourism, fisheries, and conservation activities organized by stakeholders.

\subsection{Methodology}

Figure 2 shows the summary of the research methodology conducted in this work. Contentious transect methods are used on assessing the mangrove vegetation, while fields were performed to obtain information on the fauna species. An interview was done to collect data on ecological aspects, supporting the field observations data.

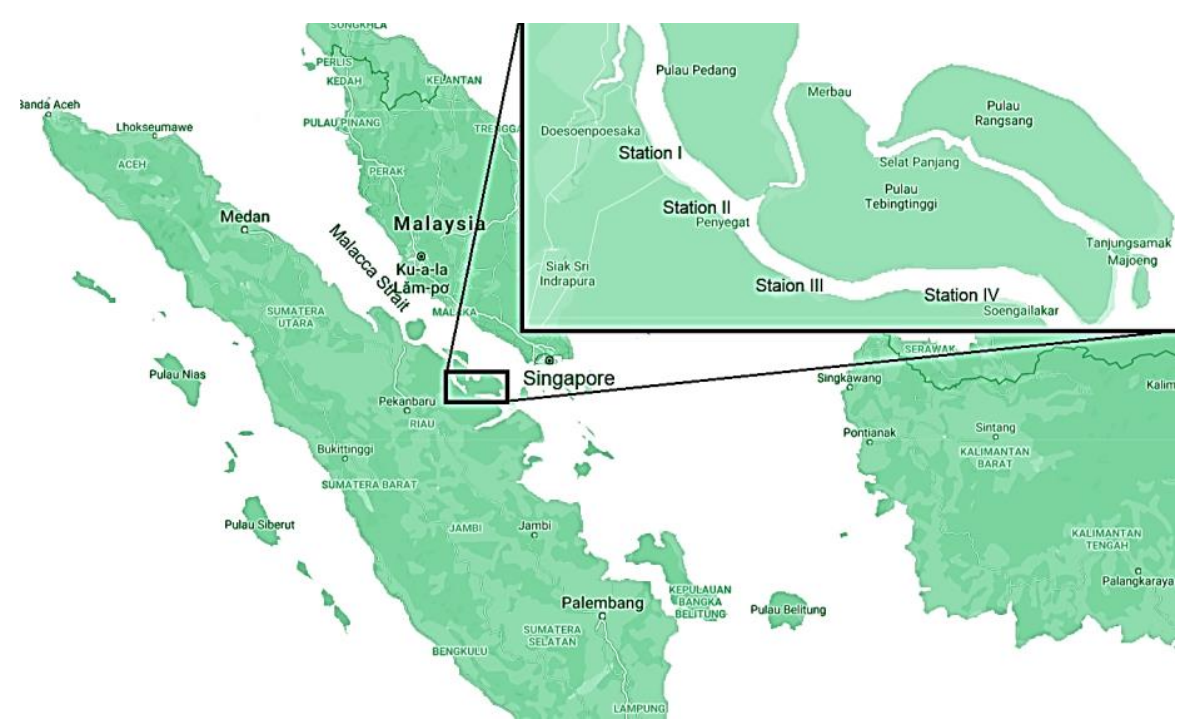

Figure 1. Sampling locations

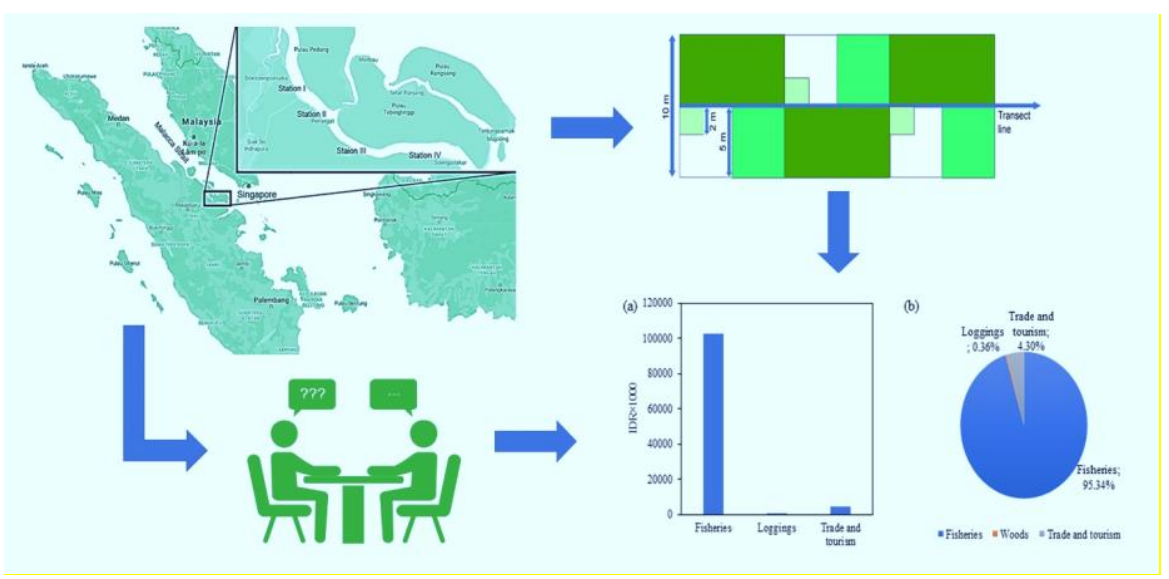

Figure 2. Research methodology summary 


\subsubsection{Transect}

Figure 3 shows a series of sample plots, referred to as a cluster. The transects were formed using sample plots or sample units with an area expected to represent the condition of the entire population in question. Sample plots were created in this stage, with each largest plot measuring $10 \mathrm{~m} \times 10 \mathrm{~m}$ since the observation area has a high density of mangrove trees. The measuring plot was lined up lengthwise to form a cluster of plotted lines perpendicular to the coastline, starting from the coast towards the land, according to the mangrove's thickness. Subsequently, an inventory of the mangrove vegetation was conducted using the plotted path method [8].

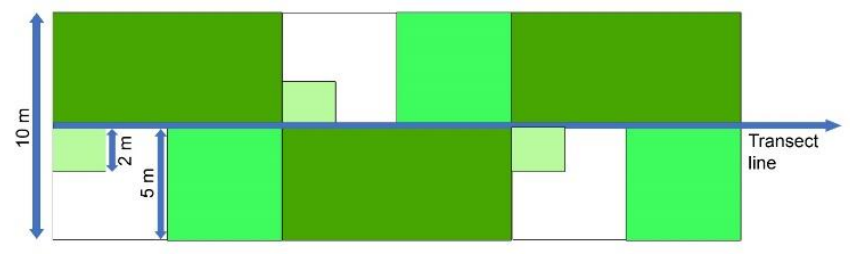

Figure 3. Plotted path transect method for floristic inventory

Although the plotting path method can become very tedious in assessing the separated individual species, this method has advantages to more effectively study the changes of vegetation according to the density of mangroves from the coastline. Meanwhile, the cluster design was placed in a pioneering direction cutting perpendicular to the shoreline, with a width of $10 \mathrm{~m}$ and a length depending on field conditions. The tree strata were then classified based on previous studies [8, 18, 19]. In addition, seedlings as well as undergrowth seedlings $(\mathrm{h} \leq 1.5$ $\mathrm{m}$ ), saplings (height $1 \mathrm{~m}$ to $<4 \mathrm{~cm}$ in diameter), and the tree strata (stem diameter $4 \mathrm{~cm}$ ) were verified within a $2 \times 2 \mathrm{~m}$ subplot, a $5 \times 5 \mathrm{~m}$ subplot, and a $10 \times 10 \mathrm{~m}$ subplot, respectively.

The mangrove vegetation parameter was chosen because it is assumed to be able to contribute to the key value of the ecological dimension, one dimension of which is assessed and analyzed for its position against other dimensions in the concept of sustainability. The parameters used to describe the condition of mangrove vegetation at each research station are based on previous studies $[20,21]$ and include the percentage density of a species to the total density of all species (relative density (RD)), the percentage of the frequency of a species to the sum of the frequencies of all species (relative frequency (RF)), percentage of the dominance of a species to the total dominance of all species (relative dominance (RDC)), important value index (IVI), which is the sum of the calculated parameters (RD, RF, and RDC). The values of RD, RF, RDC, and IVI are calculated using Eq. (1), Eq. (2), Eq. (3), and Eq. (4) respectively. In this study, the RDC was not calculated at the seedling level because only the number of species was counted during data collection. However, at the sapling and tree levels, the number of species, as well as the stem circumference, were recorded.

$$
R D=\frac{\text { sum of individual species }}{\text { transect area }}
$$

$$
\begin{gathered}
R F=\frac{\text { sum of transect area that species found }}{\text { suum of transect area }} \\
R D C=\frac{\text { dominance of calculated species }}{\text { dominance of all sepcies }}
\end{gathered}
$$

$$
I V I=R D+R F+R D C
$$

\subsubsection{Soil salinity measurement}

Soil parameters were chosen because they are assumed to contribute key values to the ecological dimension. To assess the ecological dimension, various parameters are needed, not only the condition of the vegetation but also the physical condition of the edaphic and various other biotic factors. The soil EC analysis method is done by the principle of the electrical effect of an electrolyte, is a concise and most universal analytical method for a soil salinity assessment [22]. The soil samples located $500 \mathrm{~m}$ behind the mangrove ecosystem sample were collected by digging $30 \mathrm{~cm}$ at 3 points, with a $100 \mathrm{~m}$ distance between points. Subsequently, the soil samples from the three points were mixed and analyzed. During determining soil salinity using EC, several probable factors will distract soil salinity measurements to a certain extent, such as electrophoretic mobility, soil salt composition, soil-water ratio, solution total salinity, solution temperature, and constant of the cell conductance [22].

\subsubsection{Field observation}

Field observations were performed to obtain information on the fauna species in the mangrove ecosystem area. Data were obtained through direct observation as well as information from literature and residents (regarding the types of fish caught by fishermen). Subsequently, the mangrove's economic value for the surrounding community was determined by calculating the value of direct benefits, in the form of products, for instance, capture fisheries, wood, food, recreation, and medicine. Meanwhile, an interview was performed to collect data on ecological aspects, to support the data obtained by field observations.

Animal data collection is done by direct observation. This was done with the support of literature studies, in which several parties had made observations as well. Direct observation is intended to find out the latest real conditions because literature studies were carried out on previous documents. While the literature study in this study is intended as a compliment, where if there are species of animals that have not been found but are found in the document, the researchers make observations once again by focusing on species that have not been recorded in direct observation.

\section{RESULTS AND DISCUSSIONS}

\subsection{Mangrove ecosystem conditions}

The Riau coastline mangrove ecosystem's ecological condition is influenced by the condition of the environmental physical parameters. This is also indirectly related to the vegetation's composition and structure, as well the life within, including fauna, especially fish, crabs, and other fishery commodities.

\subsubsection{Soil salinity}

Figure 4 shows the soil salinity in the mangrove vegetation areas. Based on the results, stations III and I had the highest and least salinity levels, respectively. Stations I, II, and IV have relatively high soil salinity, while station III's counterpart is very high. According to a previous study, soil salinity has a positive correlation with several mangrove vegetation biomass (i.e., tree size and flowering) [23], and the other [5, 24]. 
Furthermore, at station III, the dominant plant species on the coast was the Avicennia marina, while at station I, the dominant composition on the coast was Rhizophora mucronata (White Mangroves). Stations III and I were observed using a measuring plot for up to 20 and 40 meters across the coastline, respectively. Previous studies by Banerjee et al. [5] and Cooray et al. [25] showed Avicennia marina grows on high salinity soils and acts as a pioneer on the coast because the strong roots can withstand the waves.

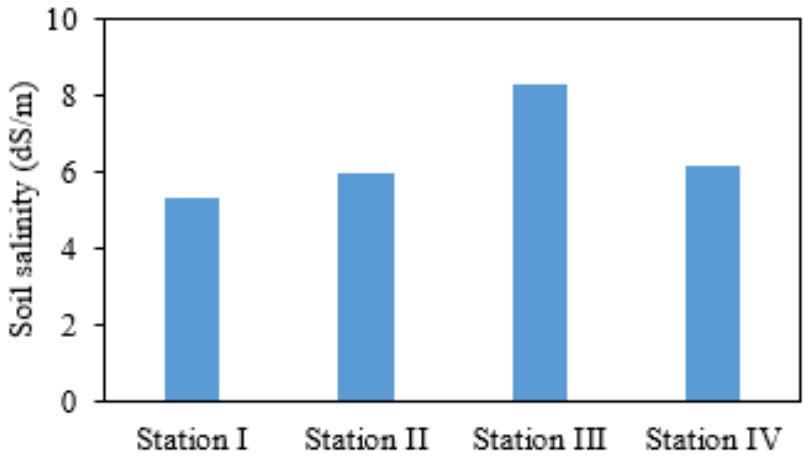

Figure 4. Soil salinity of observation stations in Riau coastlines' mangrove vegetation area

In addition, the type of substrate found in the two observation stations differed, with station I having a dark sandy mud substrate, and station III having more light-colored sand. This type of substrate corresponds to the type of plant growing. At station 1, the mud substrate is overgrown with the more stenohaline stilt root plants [26]. Meanwhile, the mud substrate at station III is overgrown, with more euryhaline pneumatophores or prop root vegetation [25, 27]. Thus, the soil condition behind the coastline is related to the type and thickness of the plant species growing and affects the land salinity level $[26,27]$. The thick mangrove ecosystem with root types adaptive to the influence of seawater and the substrate conditions [25], affects reducing the seawater intrusion on the land behind the shoreline $[3,5]$.

The soil variables have a pairwise correlation with the structural variables for linking the mangrove vegetation with the environment [24]. The soil salinity is likely to be reduced with the increasing distance from the coastline to the upland [5]. An increase in soil salinity was found to be having a great impact on the vegetation community and structure [20, 5]. Also, the presence of mangrove leaves and litter inland could decrease the soil salinity because of the enhanced addition of fresh organic carbon [20, 27].

\subsubsection{Mangrove vegetation composition and structure}

Table 1 shows the composition of mangrove species found in the Riau coastline. A total of 17 species belonging to 11 families, were identified. The vegetation is mostly dominated by the Rhizophoraceae family, comprising Rhizophora mucronata, Rhizophora apiculata, Bruguiera gymnorhiza, and Bruguiera sexangulata. Meanwhile, the least dominant vegetation belongs to the Lythraceae family and comprises the Sonneratia alba species. This is in line with the previous study [21] stating Rhizophoraceae dominate the mangrove species on the Sumatra coast, followed by Meliaceae and Avicenniaceae.

Mangrove vegetation data at each research station has a varied composition and structure of values. Therefore, there are differences in the character of each plant species at each observation station (Figure 5). Based on the results, 11 species were identified at station I, dominated by the Rhizophoraceae family in all growth strata, especially Rhizophora mucronata. This species had the highest RDC and IVI in all mangrove growth strata, compared to other species (IVI tree: 123). The species with the highest RDC and IVI, in this case, Rhizophora mucronata, played an important role in maintaining the mangrove community's stability at station I. Furthermore, the seedling strata comprised only Rhizophora mucronata, indicating the regeneration of other species are experiencing obstacles probably due to natural or human factors.

Table 1. Mangrove species found in Riau coastline

\begin{tabular}{|c|c|c|c|}
\hline Family & $\begin{array}{l}\text { Local } \\
\text { names }\end{array}$ & Species & Abb. \\
\hline \multirow[t]{4}{*}{ Rhizoporaceae } & Bakau putih & $\begin{array}{l}\text { Rhizophora } \\
\text { mucronata }\end{array}$ & $\mathrm{RM}$ \\
\hline & $\begin{array}{l}\text { bakau } \\
\text { merah }\end{array}$ & Rhizopora apiculata & RA \\
\hline & putut & Brugueira qymnoriza & BG \\
\hline & Temusing & $\begin{array}{c}\text { Brugueira } \\
\text { sexangulata }\end{array}$ & BS \\
\hline Acanthaceae & $\begin{array}{l}\text { Api-api } \\
\text { putih }\end{array}$ & Avicenia marina & $\mathrm{AM}$ \\
\hline Meliaceae & Nyirih & Xylocarpus granatum & $\mathrm{XG}$ \\
\hline \multirow[t]{3}{*}{ Malvaceae } & Baru-baru & Thespesia popylnea & $\mathrm{TP}$ \\
\hline & Dungun & Heritiera littoralis & HL \\
\hline & Dungun & Heritiera globasa & HG \\
\hline Pandanaceae & Pandan duri & Pandanus tectonus & PT \\
\hline Rubiaceae & Cingam & $\begin{array}{l}\text { Scyphiphora } \\
\text { hyropylacea }\end{array}$ & SH \\
\hline Icanaceae & Bedaru & Canteyla corniculata & $\mathrm{CC}$ \\
\hline \multirow[t]{2}{*}{ Combretaceae } & Teruntum & Lumnitzera racemosa & LR \\
\hline & Ketapang & Terminalia catappa & TC \\
\hline Euphorbiaceae & Bebatak & Excoecaria agallocha & EA \\
\hline Lynthraceae & Perepat & Sonneratia alba & SA \\
\hline Arecaceae & Nipah & Nypa fruticans & $\mathrm{NF}$ \\
\hline
\end{tabular}

A total of 6 species were identified at station II, dominated by Rhizophora apiculata at the tree strata and Avicennia marina at the sapling strata. The results showed Rhizophora apiculata species had the highest RDC and IVI (95). In addition to contributing significantly to the mangrove vegetation community, this species also shows adaptability to the environmental conditions at station II. This is similar to the report by Hanggara et al. [21] stating Rhizophora apiculata plays an important role in the North Sumatra coast. A study by Yudha et al. [8] also reported similar results for similar studies in Guinea Island.

A total of 12 species were identified at station III, dominated by the Rhizophoraceae family, comprising Rhizophora mucronata, Rhizophora apiculata, and Bruguiera gymnorhiza. The results showed Avicennia marina and Rhizophora mucronata had the highest RDC and IVI at the sapling (IVI: 46) and tree (IVI: 80), respectively. Avicennia marina species also had lower regeneration, compared to Rhizophora mucronata and Rhizophora apiculata.

The existence of this species is directly affected by seawater with constantly inundated conditions. Therefore, the species' location at the end of the beach poses a challenge to the regeneration process. However, Rhizophora mucronata and Rhizophora apiculata are located behind the Avicennia marina and have a regeneration process hindered by exposure to destructive seawater. These two species can grow in the polyhaline zone [28], and are, therefore, able to dominate the ecosystem. 

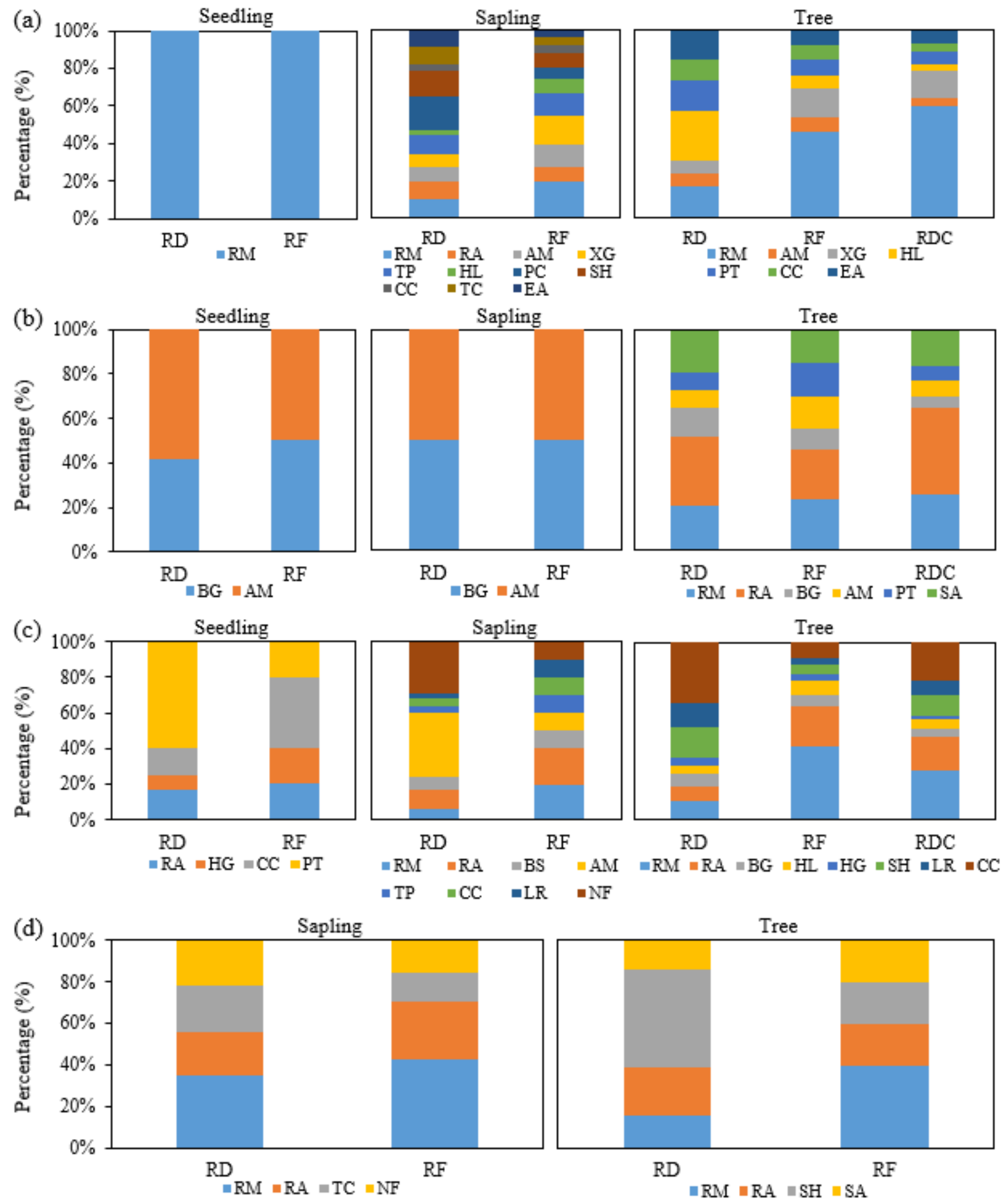

Figure 5. Mangrove condition parameters of tree strata in each observation station: (a) Station I, (b) Station II, (c) Station III, and (d) Station IV

Meanwhile, a total of 7 species were identified at station IV, also dominated by Rhizophora mucronata at the sapling strata (IVI: 46). The tree strata in this station are dominated by other species from the Rubiaceae family, particularly Scyphiphora hydrohyllacea (VI: 40), a unique monotypic genus in India, Indochina Malay Archipelago [29].

\subsubsection{Diversity index $\left(\mathrm{H}^{\prime}\right)$ of mangrove species}

The Shanon-Wienner species diversity index describes the condition of the mangrove vegetation population, where is $\mathrm{H}^{\prime}$
$1,1<\mathrm{H}^{\prime}<3$, and $\mathrm{H}^{\prime}>3$ indicate low, moderate, and high diversity, respectively [30, 31]. Figure 6 shows a comparison of each station's H' value. Based on the results, stations I and II had the least and highest $\mathrm{H}^{\prime}$ in all strata, respectively. This indicates the vegetation in station I tend to be homogeneous, despite having the largest number of individuals, because the diversity is low. The seedling strata at the station I had H'O because the vegetation at station II tended to be the most varied or heterogeneous. Station IV also has a 0 value H', because no seedling strata individuals were present in the research plot. 


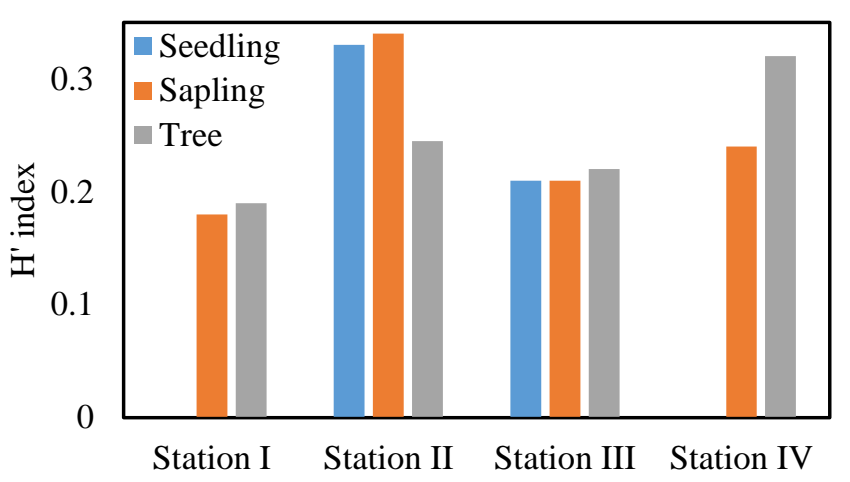

Figure 6. Diversity index $\left(\mathrm{H}^{\prime}\right)$ of mangrove species in the observation station

Suitable environmental conditions, including a muddy substrate, less inundation, and insignificant land conversion activity, enable the Rhizophoraceae family to thrive naturally at station I. This makes the vegetation in this station homogeneous, and consequently, with the least $\mathrm{H}^{\prime}$ value. This vegetation family, especially Rhizophora mucronata grows widely and is found everywhere in the mangrove ecosystem [32]. Meanwhile, environmental conditions at station II are more significantly affected by human activities, for instance, past logging, planting activities, and efforts to conserve species collections, as well as the presence of a shipping port, and these lead to changes in the flora's structure and diversity [33].

Station III has a low H' after station I, because the substrate tends to be suitable for growing Avicennia marina, and these species are directly affected by seawater and waves. Therefore, the homogeneity is more for the Avicennia marina because the species has a great survival rate [34], but grows mostly in the sapling strata. Meanwhile, station IV has a high $\mathrm{H}^{\prime}$ after station II because, apart from the true mangrove groups, Rhizophora mucronata, and Rhizophora Apiculata, the area is also overgrown with the associated mangrove groups, Pandanus tectonus, Thespesia populnea, Nypa fruticans, as well as Terminalia catappa.

Interestingly, this study discovered a globally rare and vulnerable mangrove species existing as a single species, with no variations. However, special attention is required for the species' management. The Scyphiphora hydrophyllacea, locally referred to as Cingam, is an endangered species classified into the Least Concern (LC) category with the $20 \%$ global loss criteria of the International Union for the Conservation of Nature (IUCN) Red List of Threatened Species $[35,36]$.

\subsubsection{Fauna conditions}

Figure 7 shows the diversity of fauna species found in Riau Coastline's mangrove ecosystem and the surroundings. A total of $12,2,5,5$, and 3 species of fish/water biota, amphibians, birds, reptiles, as well as mammals, respectively, were identified, with the most diverse and least diverse fauna group being fish/water biota, and amphibians, respectively.

Meanwhile, Table 2 shows the fauna species found in Riau Coastlines' mangrove ecosystem and the respective conservation statuses. The fish/water biota species present have economic value, and, therefore, mostly serve as a catch for local fishermen [37-39]. However, the existence of fish/water biota is maintained, provided the mangrove ecosystem exists. The ecosystem serves as a settling or spawning habitat for fish/water biota before going to deeper seas, and acts as a complex provider of nutrients and protection. For instance, the Scomberomorus fish has a diet of Engraulidae fish, particularly Ilisha elongata as well as Stolephorus dubious, and was found in this study. Stolephorus dubious, phytoplankton, and zooplankton often found in the mangrove ecosystem due to the abundance of detritus and other nutritional sources within were also found [40].

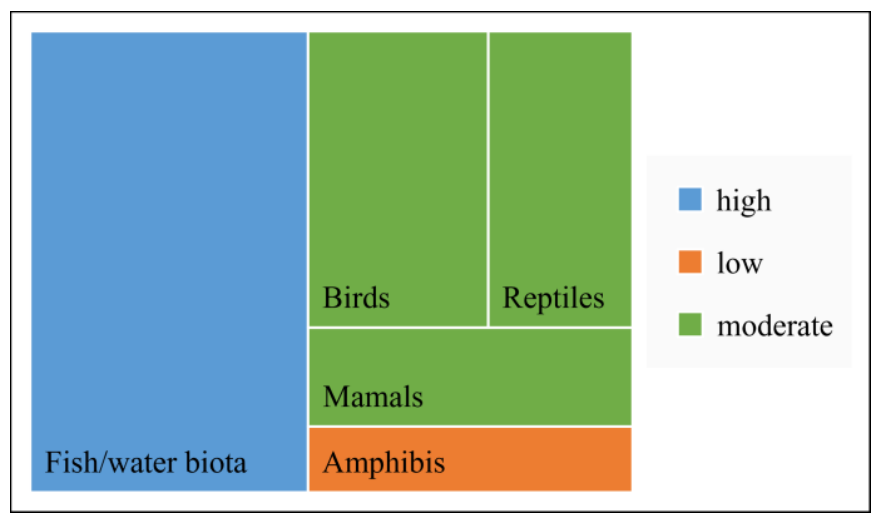

Figure 7. The diversity of fauna species

A total of 2 amphibian species, both from the same family, were found. The two species, Rana limnocharis (Swamp Frog) and Rana cancrivora (Mangrove Frog) are commonly found in mangrove ecosystems with unprotected status and low species diversity. Ranidae frogs are present in a wide variety of forests, however, only a few species survive in mangrove ecosystems [41]. This is because the water's salinity is probably unsuitable for the frog's relatively permeable skin [42].

Meanwhile, a total of 5 bird species from 4 different phyla with high diversity, were identified. According to the IUCN, these birds are protected species classified as low risk in the category of heading for extinction, particularly the whitecollared Kingfisher Halcyon chloris and Butorides striata. These species tend to be solitary or live in small colonies within mangrove trees and are also found in the mangrove forest of Papua Island [8]. The birds prey on smaller animals, including small fish, shrimp, as well as insects, and forage in the sea through exposed rocks and coral reefs, after the sea recedes. Corvus enda and Merops philipphinus are common insectivorous species found in swamps, open forests, and mangrove forests, while Haliaeetus cirrhatus, a large eagle, lives on the coast and eats smaller birds, fish, as well as snakes. This ecosystem is a good food provider for birds, especially for these species, and is, therefore, suitable habitat for all types of birds [8].

In this study, 4 reptile species from 4 different phyla with moderate diversity, were also identified. The snake species found in the mangrove ecosystem use the environment as their primary habitat. Boiga dendrophila, a snake, is commonly found in the canopy seeking for birds to prey on [43], while Enhydris enhydris, a water snake, preys on fish [44]. Meanwhile, the lizard species found were Varanus salvator and Mabouya multifasciata. Large lizards, for instance, Varanus salvator are found on riverbanks as well as in mangrove vegetation [7].

In addition, a total of 3 mammal species from 2 families with moderate diversity, were identified in this study. Macaca fascicularis, one of these species, is included in the Appendix II category of CITES (Convention on International Trade in 
Endangered Species of Wild Fauna and Flora), particularly in the vulnerability status, based on the convention on international trade in endangered species of wild plants and animals. The Appendix II category is a list of species not threatened with extinction, but have the potential to be threatened with extinction, provided unregulated trade ensues. Macaca fascicularis utilizes the mangrove ecosystem only to find food and lives in coastal forests or associated groups with higher vegetation types than the original vegetation.

\subsection{Economic values}

The mangrove ecosystem's existence provides benefits for the local community, especially fishermen $[1,2]$. In addition to catching fish, shrimp, and crabs within and around the area, the community also uses mangroves as a source of daily needs, including firewood for boiling water, to sell around the area, mostly developed for ecotourism. The ecotourism strategy provides benefits for the local community and aids ecological learning for sustainability [45].

Figure 8 shows the average value of the direct benefits enjoyed per person, in Riau Coastline. Based on this study, the total direct benefit value of the mangrove ecosystem obtainable by each person is IDR. 107,501,195, per year, from fish catches, indicating the ecosystem has a high economic value. Fishing as an occupation has a greater intensity in accessing this ecosystem, compared to other occupations.

Furthermore, ecotourism has attracted the interest of other environmentalists, including academics, Non-Governmental Organizations (NGOs), local governments, and the general public. This attractiveness has made various parties unite to organize activities, including counseling on the importance of mangrove conservation, marketing training for ecotourism destinations, and developing tourism products, for instance, tour packages, fishing tours, and producing snacks (syrup and sweets), as well as medicine, from mangroves. These training activities have a positive impact on the community and promote the establishment of mangrove ecotourism destinations.

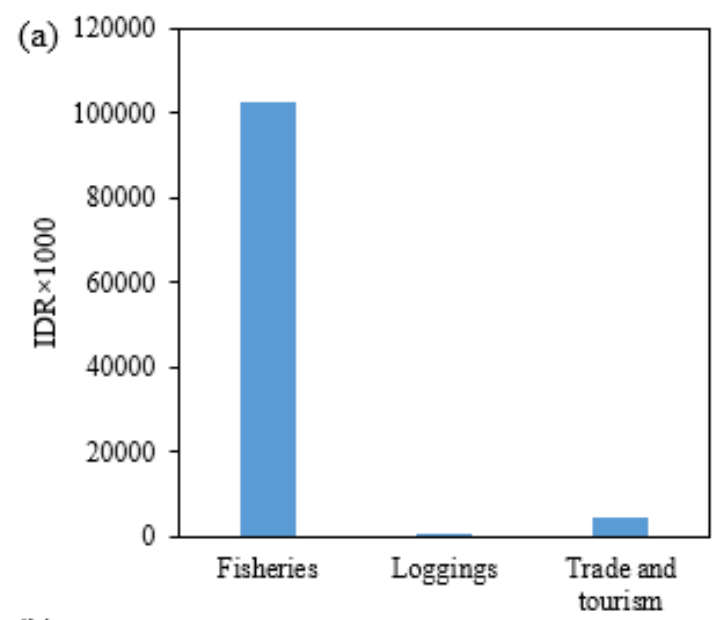

(b)

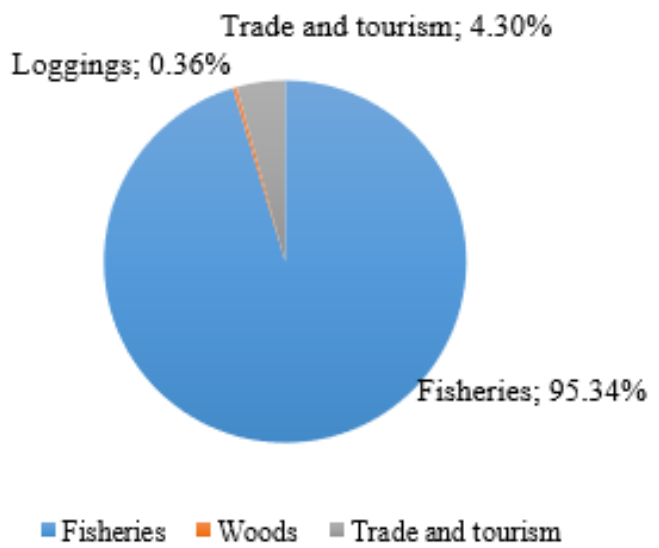

Figure 8. The benefit values of mangrove ecosystem per person: (a) Benefit per persons in a year, and (b) Percentage

Table 2. The fauna species found in Riau Coastlines' mangrove ecosystem and its conservation status

\begin{tabular}{ccccc}
\hline Fauna & Species & Family & Endemic & Conservation status \\
\hline Fish/ & Harpodon nehereus & Synodotidae & Endemic & Not protected \\
water & Otolithoides pama & Sciaenidae & Endemic & Not protected \\
biota & Ilisha elongata & Engraulidae & Endemic & Not protected \\
& Scomberomorus & Sombridae & Endemic & Not protected \\
& Muraenesox talaban & Muraenesocidae & Endemic & Not protected \\
& Stolephorus duboisus & Engraulidae & Endemic & Not protected \\
& Pumpus sp & Bramidae & Not endemic & Not protected \\
& Aphases sp & Palinuridae & Endemic & Not protected \\
& Oratosquila oratoria & Squillidae & Endemic & Not protected \\
& Penaeus merquensis & Panaeidae & Not endemic & Not protected \\
& Parapenaeiis perezfarato & Parapenaeidae & Not endemic & Not protected \\
& Charybdis annulata & Portunidae & Not endemic & Not protected \\
Amphibi & Rana limnocharis & Ranindae & Not endemic & Not protected \\
& Rana cancrivora & Ranindae & Not endemic & Not protected \\
& Halcyon chloris & Alcedinidae & Not endemic & Protected \\
& Butorides striata & Alcedinidae & Not endemic & Protected \\
& Corvus anea & Corvidae & Not endemic & Not protected \\
& Merops philippinus & Meropidae & Not endemic & Not protected \\
& Haliaeeius cirrhatus & Accipitridea & Not endemic & Protected \\
Reptiles & Boiga dendropila & Colubridae & Not endemic & Not protected \\
& Enhydris en hydris & Homolopsidae & Not endemic & Not protected \\
& Varamus salvator & Varanidae & Not endemic & Not protected \\
& Mabouya multifaciata & Scincidae & Not endemic & Not protected \\
Mamals & Macaca fascucilaris & Ceropithecidae & Not endemic & Not protected \\
& Cynopterus & Pteropodidae & Not endemic & Not protected \\
& Rattus & Muridae & Not endemic & Not protected \\
\hline & & & &
\end{tabular}


This research has assessed the impact of local community activities on the sustainability of the mangrove ecosystem. On the other hand, details of all aspects of community life that depend on mangrove ecosystems such as fisheries, logging, and ecotourism are still needed. The impact of the times and the development of technology, as well as land development on the mangrove ecosystem, also needs to be investigated further.

\section{CONCLUSIONS}

The mangrove species in the Riau coastline comprise 17 species from 11 families, dominated by the Rhizophoraceae family, consisting of Rhizophora mucronata, Rhizophora apiculata, Bruguiera gymnorhiza, and Bruguiera sexangulata, with a low species diversity index of $0.10-0.37$ and a mangrove area of 6,840.4 ha. Meanwhile, the fishery biota, including fish, shrimp, and crabs, are the main commodities traded by the local community, because logging of mangrove forests is a less attractive source of income. In addition, the promotion of ecotourism also increases public awareness of sustainability and serves as an economic booster.

This research only assessed the impact of local community activity on the sustainability of the mangrove ecosystem. Even though it is sustainable, community activities in utilizing the mangrove ecosystem must continue to be monitored to ensure sustainability. Further research is needed on strategies for developing mangrove ecosystems to keep pace with technological developments and community needs in the future.

\section{ACKNOWLEDGMENT}

The author would like to thank the Siak Regency Government for supporting and granting permission for this research.

\section{REFERENCES}

[1] Sukendi, S., Mariana, M. (2017). Correlation of above ground biomass carbon storage and productivity of mangrove species. International Journal of Applied Environmental Sciences, 10(4): 1403-1410.

[2] Zulkarnaini, Mariana. (2016). Economic valuation of mangrove forest ecosystem in Indragiri estuary. International Journal of Oceans and Oceanography, 10(1): 13-17.

[3] Plaziat, J.C., Cavagnetto, C., Koeniguer, J.C., Baltzer, F. (2001). History and biogeography of the mangrove ecosystem, based on a critical reassessment of the paleontological record. Wetlands Ecology and Management, $\quad 9(3)$ : $161-180$. https://doi.org/10.1023/A:1011118204434

[4] Gnansounou, S.C., Toyi, M., Salako, K.V., Ahossou, D.O., Akpona, T.J.D., Gbedomon, R.C., Assogbadjo, A.E., Glèlè Kakaï, R. (2021). Local uses of mangroves and perceived impacts of their degradation in GrandPopo municipality, a hotspot of mangroves in Benin, West Africa. Trees, Forests and People, 4: 100080. https://doi.org/10.1016/J.TFP.2021.100080

[5] Cooray, P.L.I.G.M., Jayawardana, D.T., Gunathilake,
B.M., Pupulewatte, P.G.H. (2021). Characteristics of tropical mangrove soils and relationships with forest structural attributes in the northern coast of Sri Lanka. Regional Studies in Marine Science, 44: 101741. https://doi.org/10.1016/j.rsma.2021.101741

[6] Sukuryadi, Harahab, N., Primyastanto, M., Semedi, B. (2021). Collaborative-based mangrove ecosystem management model for the development of marine ecotourism in Lembar Bay, Lombok, Indonesia. Environment, Development and Sustainability, 23(5): 6838-6868. https://doi.org/10.1007/s10668-020-00895-8

[7] Mahmood, H., Ahmed, M., Islam, T., Uddin, M.Z., Ahmed, Z.U., Saha, C. (2021). Paradigm shift in the management of the Sundarbans mangrove forest of Bangladesh: Issues and challenges. Trees, Forests and People, 5: 100094. https://doi.org/10.1016/j.tfp.2021.100094

[8] Yudha, R.P., Sugito, Y.S., Sillanpää, M., Nurvianto, S. (2021). Impact of logging on the biodiversity and composition of flora and fauna in the mangrove forests of Bintuni Bay, West Papua, Indonesia. Forest Ecology and Management, 488: 119038. https://doi.org/10.1016/j.foreco.2021.119038

[9] Walters, B.B., Rönnbäck, P., Kovacs, J.M., Crona, B., Hussain, S.A., Badola, R., Primavera, J.H., Barbier, E., Dahdouh-Guebas, F. (2008). Ethnobiology, socioeconomics and management of mangrove forests: A review. In Aquatic Botany, 89(2): 220-236. https://doi.org/10.1016/j.aquabot.2008.02.009

[10] Kusumaningtyas, M.A., Hutahaean, A.A., Fischer, H.W., Pérez-Mayo, M., Ransby, D., Jennerjahn, T.C. (2019). Variability in the organic carbon stocks, sources, and accumulation rates of Indonesian mangrove ecosystems. Estuarine, Coastal and Shelf Science, 218: 310-323. https://doi.org/10.1016/j.ecss.2018.12.007

[11] Ono, K., Hiradate, S., Morita, S., Hiraide, M., Hirata, Y., Fujimoto, K., Tabuchi, R., Lihpai, S. (2015). Assessing the carbon compositions and sources of mangrove peat in a tropical mangrove forest on Pohnpei Island, Federated States of Micronesia. Geoderma, 245-246: 11-20. https://doi.org/10.1016/j.geoderma.2015.01.008

[12] Rahman, M.M., Mahmud, M.A. (2018). Economic feasibility of mangrove restoration in the Southeastern Coast of Bangladesh. Ocean and Coastal Management, 161:

https://doi.org/10.1016/j.ocecoaman.2018.05.009

[13] Hernández-Blanco, M., Costanza, R., Cifuentes-Jara, M. (2021). Economic valuation of the ecosystem services provided by the mangroves of the Gulf of Nicoya using a hybrid methodology. Ecosystem Services, 49: 101258. https://doi.org/10.1016/j.ecoser.2021.101258

[14] Ashournejad, Q., Amiraslani, F., Moghadam, M.K., Toomanian, A. (2019). Assessing the changes of mangrove ecosystem services value in the Pars Special Economic Energy Zone. Ocean and Coastal Management, 179:

104838 . https://doi.org/10.1016/j.ocecoaman.2019.104838

[15] Seary, R., Spencer, T., Bithell, M., McOwen, C. (2021). Measuring mangrove-fishery benefits in the Peam Krasaop Fishing Community, Cambodia. Estuarine, Coastal and Shelf Science, 248: 106918. https://doi.org/10.1016/j.ecss.2020.106918

[16] zu Ermgassen, P.S.E., Mukherjee, N., Worthington, T.A., et al. (2021). Fishers who rely on mangroves: Modelling 
and mapping the global intensity of mangrove-associated fisheries. Estuarine, Coastal and Shelf Science, 248: 107159. https://doi.org/10.1016/j.ecss.2020.107159

[17] Carrasquilla-Henao, M., Ban, N., Rueda, M., Juanes, F. (2019). The mangrove-fishery relationship: A local ecological knowledge perspective. Marine Policy, 108: 103656. https://doi.org/10.1016/j.marpol.2019.103656

[18] Goessens, A., Satyanarayana, B., Van Der Stocken, T., Zuniga, M.Q., Mohd-Lokman, H., Sulong, I., DahdouhGuebas, F. (2014), Is Matang mangrove forest in Malaysia sustainably rejuvenating after more than a century of conservation and harvesting management? Plos One, 9: 10506 https://doi.org/10.1371/journal.pone.0105069

[19] Sillanpää, M., Vantellingen, J., Friess, D.A. (2017). Vegetation regeneration in a sustainably harvested mangrove forest in West Papua, Indonesia. Forest Ecology and Management, 390: 137-146. https://doi.org/10.1016/j.foreco.2017.01.022

[20] Datta, D., Deb, S. (2017). Forest structure and soil properties of mangrove ecosystems under different management scenarios: Experiences from the intensely humanized landscape of Indian Sunderbans. Ocean and Coastal Management, 140: 22-33. https://doi.org/10.1016/j.ocecoaman.2017.02.022

[21] Hanggara, B.B., Murdiyarso, D., Ginting, Y.R., Widha, Y.L., Panjaitan, G.Y., Lubis, A.A. (2021). Effects of diverse mangrove management practices on forest structure, carbon dynamics and sedimentation in North Sumatra, Indonesia. Estuarine, Coastal and Shelf Science, 259: 107467. https://doi.org/10.1016/j.ecss.2021.107467

[22] Liu, G.M., Yang, J.S., Yao, R.J. (2006). Electrical conductivity in soil extracts: Chemical factors and their intensity. Pedosphere, 16(1): 100-107. https://doi.org/10.1016/S1002-0160(06)60031-3

[23] Azad, M.S., Kamruzzaman, M., Ahmed, S., Kanzaki, M. (2021). Litterfall assessment and reproductive phenology observation in the Sundarbans, Bangladesh: A comparative study among three mangrove species. Trees, Forests and People, 4: 100068. https://doi.org/10.1016/J.TFP.2021.100068S

[24] Sreelekshmi, S., Joseph, P., Varghese, R., Preethy, C.M., Bijoy Nandan, S. (2020). Structural variability and its relation to edaphic attributes of mangroves in the southwest coast of India. Lakes and Reservoirs: Research and Management, 25(2): 143-156. https://doi.org/10.1111/lre.12314

[25] Banerjee, K., Sengupta, K., Raha, A., Mitra, A. (2013). Salinity based allometric equations for biomass estimation of Sundarban mangroves. Biomass and Bioenergy, 56: 382-391. https://doi.org/10.1016/j.biombioe.2013.05.010

[26] Du, Q., Qin, Z., Ming, S., Zhang, C. (2021). Differences in the vertical accretion of sediment among mangrove species with different aerial root types. Estuarine, Coastal and Shelf Science, 256: 107375. https://doi.org/10.1016/j.ecss.2021.107375

[27] Nagelkerken, I., Blaber, S.J.M., Bouillon, S., Green, P., Haywood, M., Kirton, L.G., Meynecke, J.O., Pawlik, J., Penrose, H.M., Sasekumar, A., Somerfield, P.J. (2008). The habitat function of mangroves for terrestrial and marine fauna: A review. In Aquatic Botany, 89(2): 155185. https://doi.org/10.1016/j.aquabot.2007.12.007

[28] Ahmed, S., Kamruzzaman, M., Azad, M.S., Khan, M.N.I.
(2021). Fine root biomass and its contribution to the mangrove communities in three saline zones of Sundarbans, Bangladesh. Rhizosphere, 17: 100294. https://doi.org/10.1016/j.rhisph.2020.100294

[29] Tan, H.T.W., Rao, A.N. (1988). Sporogenesis and Gametogenesis in Scyphiphora hydrophyllacea Gaertn. f. (Rubiaceae). Flora, 180(5-6): 413-416. https://doi.org/10.1016/s0367-2530(17)30333-x

[30] Singh, J.K. (2020). Structural characteristics of mangrove forest in different coastal habitats of Gulf of Khambhat arid region of Gujarat, west coast of India. Heliyon, 6(8): e04685. https://doi.org/10.1016/j.heliyon.2020.e04685

[31] Fu, S., Rao, Y., Chen, X., Zhou, X., Wu, C., Li, X., Peng, W., Cai, L. (2021). Comparison of benthic nematode assemblages in native mangrove forest and exotic mangrove plantations (Sonneratia apetala Buch-Ham) along the South China Coast. Marine Pollution Bulletin, 166:

112249 . https://doi.org/10.1016/j.marpolbul.2021.112249

[32] Sari, S.P., Rosalina, D. (2016). Mapping and monitoring of mangrove density changes on tin mining area. Procedia Environmental Sciences, 33: 436-442. https://doi.org/10.1016/j.proenv.2016.03.094

[33] Sahadevan, A.S., Joseph, C., Gopinath, G., Ramakrishnan, R., Gupta, P. (2021). Monitoring the rapid changes in mangrove vegetation of coastal urban environment using polynomial trend analysis of temporal satellite data. Regional Studies in Marine Science, 46: 101871. https://doi.org/10.1016/j.rsma.2021.101871

[34] Tamin, N.M., Zakaria, R., Hashim, R., Yin, Y. (2011). Establishment of Avicennia marina mangroves on accreting coastline at Sungai Haji Dorani, Selangor, Malaysia. Estuarine, Coastal and Shelf Science, 94(4): 334-342. https://doi.org/10.1016/j.ecss.2011.07.009

[35] Polidoro, B.A., Carpenter, K.E., Collins, L., et al. (2010). The loss of species: Mangrove extinction risk and geographic areas of global concern. PLoS ONE, 5(4): 10095. https://doi.org/10.1371/journal.pone.0010095

[36] Chen, Y., Wei, X., Lin, G., Liu, Y., Zhang, Y. (2020). The complete mitochondrial genome of an endangered mangrove plant: Scyphiphora hydrophyllacea. Mitochondrial DNA Part B, 5(3): 2779-2780. https://doi.org/10.1080/23802359.2020.1788460

[37] Vorsatz, L.D., Pattrick, P., Porri, F. (2021). Ecological scaling in mangroves: The role of microhabitats for the distribution of larval assemblages. Estuarine, Coastal and Shelf Science, 253: 107318. https://doi.org/10.1016/j.ecss.2021.107318

[38] Enchelmaier, A.C., Babcock, E.A., Hammerschlag, N. (2020). Survey of fishes within a restored mangrove habitat of a subtropical bay. Estuarine, Coastal and Shelf Science, 244: 106021. https://doi.org/10.1016/j.ecss.2018.11.009

[39] Kendall, M.S., Siceloff, L., Monaco, M.E., Ruffo, A., Winship, A.J., Holloway, N.H. (2021). Measuring mutual movements, mixing, and mingling among multiple mangrove bays by an important estuarine sea bream (Archosargus rhomboidalis). Estuarine, Coastal.

[40] Syafei, L.S., Siregar, R.S., Rahardjo, M.F., Simanjuntak, C.P.H. (2020). Diet composition and trophic niche similarities of engraulid fishes in Pabean bay, Indramayu, Indonesia. IOP Conference Series: Earth and Environmental Science, 404: 012056. 
https://doi.org/10.1088/1755-1315/404/1/012056

[41] Jaafar, I., Hurzaid, A., Shahrudin, S., Ibrahim, N.H., Awang, Z., Majid, N.A., Zaaba, N.H.C. (2013). Updated checklist of amphibians of Pulau Jerejak, Penang, Peninsular Malaysia. Procedia - Social and Behavioral Sciences, 91: 36-40. https://doi.org/10.1016/j.sbspro.2013.08.398

[42] Kearney, B.D., Byrne, P.G., Reina, R.D. (2012). Larval tolerance to salinity in three species of Australian anuran: An indication of saline specialisation in Litoria aurea. $\begin{array}{lll}\text { PLoS ONE, } & \text { 7(8): }\end{array}$ https://doi.org/10.1371/journal.pone.0043427

[43] Pawlak, J., Mackessy, S.P., Fry, B.G., Bhatia, M., Mourier, G., Fruchart-Gaillard, C., Servent, D., Ménez, R., Stura, E., Ménez, A., Kini, R.M. (2006). Denmotoxin, a three-finger toxin from the colubrid snake Boiga dendrophila (mangrove catsnake) with bird-specific activity. Journal of Biological Chemistry, 281(39): 29030-29041. https://doi.org/10.1074/jbc.M605850200

[44] Pongcharoen, C., Voris, H.K., Seelanan, T., Pradatsundarasar, A.O., Thirakhupt, K. (2016). Diet, female reproduction and conservation of Jagor's water snake, Enhydris jagorii in Bung $\mathrm{Ka}$ Loh wetland, Uttaradit province, Thailand. Agriculture and Natural Resources, 50(3):

204-210.

https://doi.org/10.1016/j.anres.2015.12.002

[45] Surjanti, J., Soejoto, A., Seno, D.N., Waspodo. (2020). Mangrove forest ecotourism: Participatory ecological learning and sustainability of students' behavior through self-efficacy and self-concept. Social Sciences \& Humanities Open, 2(1): 100009. https://doi.org/10.1016/j.ssaho.2019.100009 